Araştırma Makalesi

\title{
Üniversite Öğrencilerinin Akademik Öz-Yeterlilik ve Yaşam Kalitelerinin Fiziksel Aktivite Yapma Durumlarına Göre İncelenmesi*
}

\author{
Bnar Muhamed HAMAD AMİN ${ }^{1}$
}

Funda ÇOŞKUN ÖZYOL ${ }^{2}$

\section{$\ddot{\mathbf{O} z}$}

Bu çalışmanın temel amacı Van Yüzüncü Yıl Üniversitesi lisans öğrencilerinin akademik öz-yeterlik ve üniversite yaşam kalitesine ilişkin algılarını ve bu algıların cinsiyet ve fiziksel aktivite yapma durumuna göre farklılaşıp farklılaşmadığını incelemektir. Çalışmaya Van Yüzüncü Yıl Üniversitesi'nde eğitim gören ve yaşları 18 ile 29 arasında değişen 2185 kadın ve 2493 erkek olmak üzere toplam 4678 öğrenci katılmıştır. Kullanılan veri toplama araçları Kişisel Bilgi Formu, Üniversite Yaşam Kalitesi Ölçeği ve Akademik ÖzYeterlik Ölçeği'dir. Elde edilen verilerin analizinde betimsel istatistikler ve Mann Whitney-U testi kullanılmışıı. Araştırma bulguları katılımcıların akademik öz-yeterlik puan ortalamalarının cinsiyete göre farklılaştı̆̆ını $(\mathrm{p}<.01)$, erkek öğrencilerin akademik öz-yeterlik puanlarının kadın öğrencilerden yüksek olduğunu ve erkek öğrencilerin üniversite yaşamlarını daha kaliteli algıladıklarını ortaya koymuştur $(\mathrm{p}<.01)$. Ancak araştırmada, öğrencilerinin akademik öz-yeterlik ve üniversite yaşam kalitesi puanlarının fiziksel aktivite yapma durumuna göre farklılaşmadığ 1 sonucu elde edilmiştir $(\mathrm{p}>.05)$. Sonuç olarak; üniversite öğrencilerinin üniversite yaşam kalitesi puanları ile akademik öz-yeterlik puanlarının cinsiyete göre farklılaştı̆ı̆, ancak akademik öz-yeterlik ve üniversite yaşam kalitesi algılarının fiziksel aktivite yapma durumuna göre farklılaşmadığı görülmüştür.

Anahtar Kelimeler: Fiziksel Aktivite, Üniversite Yaşam Kalitesi, Akademik Öz-Yeterlik, Üniversite Öğrencisi

\section{Examination of Academic Self-Efficacy and Quality of Life of University Students According to Their Physical Activity Status}

\begin{abstract}
The objective of this study was to document the perceptions of undergraduate students regarding academic self-proficiency and quality of university life and to evaluate whether their perceptions differed based on their physical activity levels. A total of 4.678 students aged between 18-29 (2.493 men and 2.185 women) registered at Yuzuncu Yil University in Van, Turkey, participated in this study. Data collection tools consisted of a personal information form, the Academic Self-Proficiency Scale, and the University Quality of Life Scale. Descriptive statistics, the Mann-Whitney U test were used to analyze the data. According to the results of the Mann-Whitney $U$ test, the mean academic self-sufficiency score of the male students was significantly higher than that of the female students $(\mathrm{p}<.01)$. The male students also held significantly more positive perceptions of the quality of their university lives $(\mathrm{p}<.01)$. However, significantly different results were not obtained for academic self-sufficiency or quality of university life scores with respect to physical activity levels $(\mathrm{p}>.05)$. University students' academic self-efficacy and quality of university life scores varied according to gender and a relationship between these two variables was found. Perceptions of academic self-

\footnotetext{
* Bu çalışma aynı isimli yüksek lisans tezinin bir bölümünden oluşmaktadır. Araştırma Van Yüzüncü Yı1 Üniversitesi BAPSİS SYL-2018-6881 nolu proje ile desteklenmiştir.

${ }^{1}$ Van Yüzüncü Y1l Üniversitesi, Beden Eğitimi ve Spor Yüksekokulu, Van- TÜRKIYY, bnar.m12@gmail.com, https://orcid.org/0000-0002-9458-6211

${ }^{2}$ Sorumlu Yazar: Van Yüzüncü Y1l Üniversitesi, Beden Eğitimi ve Spor Yüksekokulu, Van- TÜRKIYYE, fcoskun@yyu.edu.tr, https://orcid.org/0000-0003-0198-4331
} 
Çoşkun Özyol, F., Hamad Amin, M.B./Üniversite Öğrencilerinin Akademik Öz-Yeterlilik ve Yaşam Kalitelerinin Fiziksel Aktivite Yapma Durumlarına Göre İncelenmesi

sufficiency and quality of university life did not significantly differ on the basis of students' physical activity levels, however.

Keywords: Physical Activity, Quality of University Life, Academic Self-Efficacy, University Student.

\section{Gİiș}

İnsan yaşamının önemli bir zaman dilimine denk gelen üniversite eğitiminin, öğretim aracılığ 1 ile insan olanaklarının gelişimine katk1 sağladığ yoluyla da öğrencilerin yaşam kalitesinin yükseltilmesine yardımc1 olduğu bildirilmektedir (Kateba, 1999). Yaşam kalitesi bireylerin kendini geliştirebilmesi, hayatını kolaylaştırabilmesi ve mutlu olabilmesi için bir takım şeylere erişebilme amacı olarak tanımlanmakta ve bireyin iyi olma durumunu ifade etmektedir (Güney, 2004). Genellikle "iyi oluş" anlamına gelen yaşam kalitesi kavramı; mutluluk, tatmin, uyum, iyi olma hali ve yaşamın öznel bir değerlendirilmesi olarak da açıklanabilmekte ve aynı zamanda kişinin günlük yaşam faaliyetlerini, duygusal ve psikolojik halini, aile içi ve dışı toplumsal ahengini, çevreden etkilenmelerini içermektedir (Erdem,2005). Üniversite öğrencilerinin yaşam kalitesini etkilemesini düşünülen bir kavram olan Özyeterlik, "kişinin yetenekleri hakkında kendini inandırması" olarak tanımlanmaktadır. Algılanan öz-yeterlik (Perceived self-efficacy) veya öz yeterlik inancı (Self-efficacy beliefs) olarak bildirilen bu kavram Bandura'nın vurgulamış olduğu Sosyal Öğrenme Kuramı'nda (Social Learning Theory) dikkati çeken ve kuramın merkezini oluşturan bir kavramdır (Bandura, 1997). Bireyin var olan bir amacı ortaya koymak için gerekli olan hareketlerini yürütme ve düzenleme gücü ile ilgili yargısını içeren öz-yeterlik kavramı (Bandura, 1997; Bandura, 2000) ayn1 zamanda bireyin bu amacı gerçekleştirmesi sürecindeki çaba ve direncini etkilemesi açısından önemli görülmektedir (Kinzie ve ark., 1994). Pozitif öz-yeterlik beklentisinin motivasyonu yükselttiği, daha önce karşılaşılmamış ve başarması zor sorumlulukların üstesinden gelmek için çaba harcamaya teşvik ettiği, negatif öz-yeterlik beklentisinin de bireyin kendisinin almış olduğu kararlar ile davranış sergilemesine veya uygulamakta olduğu bir görevi sonlandırmadan ayrılmasına sebep olduğu belirtilmektedir (Jerusalem, 2002). Özyeterliğin, duygusal durum, performans başarıları, sözel ikna ve dolaylı yaşantılar olmak üzere birbirleri ile bağlantılı dört temel bileşenden oluştuğu ileri sürülmektedir (Bandura, 1997; Yavuzer ve ark., 2002). Özyeterlik kavramı çok boyutlu bir yapıdır ve bir çok davranışın kendisine ait öz-yeterlik algısı bulunmaktadır (Eskici, 2009). Bu algilar eğitim açısından incelendiginde en önemlisi “akademik öz-yeterlik”tir. Özellikle öğrenme etkinliğine odaklanıldığında akademik özyeterlik algısı daha ön plana çıkmaktadır (Eskici, 2009; Erdem, 2005).

Akademik öz-yeterlik öğrencilerin sorumlu oldukları akademik görevleri başarılı bir şekilde gerçekleştirmeye olan inançları olarak tanımlanmaktadır. $\mathrm{Bu}$ inançlar, bireylerin tutumlarına ve yeteneklerine olan inançlarına ek olarak akademik çalışmalarında başarılı olabileceklerine yönelik inançlarından etkilenmektedir (Schunk, 1991). Bu tarafı ile akademik öz-yeterlik kavramı akademik başarıya yön veren duyuşsal bir faktör olarak yorumlanmaktadır (Ekici, 2009). Akademik öz-yeterlik alg1s1 üniversitede bulunan öğrencilerin başarıya ulaşması açısından mühim bir faktördür. Çünkü üniversitede geçirilen eğitim dönemi özellikle öğrencilerin kendilerini gerçekleştirebilmelerinde hassas bir döneme denk gelmektedir. Öğrencilerin bu süreçte kendilerine güvenmeleri, bireysel olarak karar verebilmeleri, kararlarının sorumluluklarını almaları ve bireysel olarak hareket etmeleri beklenmektedir (Kandemir, 2014). Farklı örneklem grupları ile yürütülen araştırmalarda; akademik-sosyal duygusal özyeterlik algısı pozitif (olumlu) olan kişilerin benlik değerlendirmelerinin yüksek olduğu (Altun ve ark., 2013; Aypay, 2010; Hermann, 2005) ve yaşamlarından daha fazla doyum aldıkları (Caprara ve ark., 2005; Özpay ve ark., 2012; Telef ve ark., 2013; Vecchio ve ark., 2007) bildirilmiştir. Kendilerine ve 
hayatlarına ait pozitif hislere ve algilara sahip olan kişilerin ise daha aktif ve hızlı problem çözebildikleri, stresli yaşam koşullarına karşı yüksek ve saglıklı direnç gösterebildikleri gözlemlenmektedir (Huebner ve ark., 2004). Örneğin, Seki ve ark. (2018) tarafindan yapılan çalışmada üniversite öğrencilerinin yaşam kalitelerine ilişkin algılarının akademik öz-yeterliğin yordayıcısı olduğu (Seki ve ark., 2018), Wilcox ve Nordstokke (2019) tarafından yapılan çalışmada ise akademik memnuniyetin ve okul yaşam doyumunun genel yaşam doyumunu etkilediği, ancak akademik öz yeterlik ve okuldan duyulan memnuniyetin yaşam doyumunu etkilemediği sonucuna ulaşılmıştır (Wilcox ve ark., 2019). Antaramian (2017) de çalışmasında yüksek yaşam memnuniyeti olan öğrencilerin daha katılımcı ve girişken olduklarını, yüksek akademik öz yeterlik ve başarı yönelimine sahip olduklarını dile getirmiştir (Antaramian, 2017). Özetle, öğrencilerin okul içi ve okul dışı hayatın niteliklerine bir bütün olarak sunan okul ortamı, öğrencilerin kendilerini güvende ve mutlu hissettikleri, sosyal bağlantılardan ve öğrendiklerinden dolayı mutlu oldukları alandır (Sar1, 2007).

İnsan yasamının bir cok doneminde koruyucu ve destekleyici saglık bileseni olarak bilinen fiziksel aktivitenin çocuk ve gençlerin sağliklı büyüme ve gelişmelerinde, istenmeyen alışkanlıklardan korunmalarında ve sosyalleşmelerinde katk1 sağladığ bilinmektedir. Ayn1 zamanda fiziksel aktivitenin yetişkinlerin bir çok kronik rahatsızlıklardan korunmasinda veya bu rahatsızlıkların tedavi edilmesinde, tedavinin desteklenmesinde, yaşlı bireylerin aktif bir yaşl1lık süreci geçirmelerinin ve genel olarak tüm yaşam süresince yaşam kalitesinin yükseltilmesinde olumlu etkilerinin olduğu ifade edilmektedir (Tamannaeifar ve ark., 2014). Bu gerekçeden hareketle; literatür gözden geçirildiğinde çeşitli üniversite ve bölümlerde bulunan öğrencilerin akademik öz-yeterliklerini ve üniversite yaşam kalitelerini araştıran çalışmaların bulunduğu görülürken (Altun ve ark., 2012; Argon ve ark., 2009), üniversite öğrencilerinin akademik öz-yeterliklerini ve üniversite yaşam kalitelerini fiziksel aktivite yapma durumlarına göre inceleyen bir çalışma bulunamamıştır. $\mathrm{Bu}$ bağlamda yapılan bu çalışmanın amacı Van Yüzüncü Yıl Üniversitesi lisans öğrencilerinin akademik öz-yeterlik ve üniversite yaşam kalitesine ilişkin algılarını belirlemek ve bu algıların cinsiyet ve fiziksel aktivite yapma durumuna göre farklılaşıp farklılaşmadığını incelemektir.

\section{YÖNTEM}

Araştırmanın Modeli: Van Yüzüncü Yı1 Üniversitesi lisans öğrencilerinin cinsiyete göre üniversite yaşam kalitesi ve akademik öz-yeterlik algılarını belirleyerek, fiziksel aktivite yapma durumlarına göre farkı ortaya koymak amaciyla yapılan bu araştırma ilişkisel tarama modelinde kesitsel bir araştırmadır.

Katılımcılar: $\mathrm{Bu}$ araştırmanın evrenini 20172018 yıllarında Van Yüzüncü Y11 Üniversitesi'nin örgün öğrenimi tercih eden toplam 26647 lisans öğrencisi oluşturmaktadır. Araştırma örnekleminin belirlenmesinde oranlı küme örnekleme yöntemi kullanılmıştır. $\mathrm{Bu}$ bağlamda veri setinin uygulanacağı tüm fakülteler dikkate alınmış cinsiyet ve sınıf değişkeni gözetilerek katılımcılar belirlenmiştir. Evrendeki öğrenci sayısının \%20'si $\quad(\mathrm{n}=4678)$ araştırmanın katılımcıları olarak çalışmaya dahil edilmiştir. Araştırma için Van Yüzüncü Y1l Üniversitesi Rektörlügü Sosyal ve Beşeri Bilimler Etik kurulundan 01.03.2018 tarih ve 02 sayılı karar doğrultusunda yayın etiği izni alınmıştır. Araştırmada Helsinki bildirgesi etik kurallarına uyulmuştur.

\section{Veri Toplama Araçlart}

Kişisel Bilgi Formu: Çalışmada kullanılan Kişisel Bilgi Formu, ögrencilerin yas araliklar1(18-20, 21-23, 24-26, 27-29), cinsiyetleri (Kadın,Erkek) ve fiziksel aktivite yapma durumlarını (Evet/Hayır) belirlemek üzere hazırlanmış 3 sorudan oluşmaktadır.

Akademik Öz-Yeterlik Ölçeği : $\mathrm{Bu}$ araştırmada öğrencilerin akademik özyeterliklerini ortaya koymak için Jeruselel and Schwarzer tarafindan 1981'de oluşturulan ve daha sonra Türkçe'ye adaptasyonu Yilmaz ve ark. (2007) tarafından yapılan "Akademik Öz-yeterlik Ölçeğì" kullanılmıştır. Tek bir boyuttan oluşan bu ölçek 4'lü Likert tipde 7 maddeden 
Çoşkun Özyol, F., Hamad Amin, M.B./Üniversite Öğrencilerinin Akademik Öz-Yeterlilik ve Yaşam Kalitelerinin Fiziksel Aktivite Yapma Durumlarına Göre İncelenmesi

meydana gelmektedir. Ölçekten elde edilebilecek puan aralığ1 7 ile 28 arasında değişmektedir. Elde edilen yüksek puan akademik öz-yeterlik düzeyinin yüksek olduğunugöstermektedir. $\mathrm{Bu}$ ölçeğin Cronbach Alfa katsayısı .79 ve hesaplanan iç tutarlık katsayısı ise .70 olarak bildirilmiştir (Y1lmaz ve ark., 2007).

Üniversite Yaşam Kalitesi Ölçeği

Çalışmaya katılan öğrencilerin Üniversite Yaşam Kalitesi düzeylerini belirlemek amac1 ile Doğanay ve Sarı (2006) tarafından 5'li Likert tipinde oluşturulmuş "Üniversite Yaşam Kalitesi Ölçeği" kullanılmıştır. Ölçek, "Öğretim Elemanı Öğrenci İletişimi”, "Kimlik", "Sosyal Olanaklar", "Kararlara Katılım", "Öğrenci-
Öğrenci İletişimi”, "Gelecek", "Sınıf Ortamı" olmak üzere 7 alt boyut ve 33 sorudan meydana gelmektedir. Toplam varyansin \%45,82'sini açıklayan bu yedi alt ölçeğe ait Cronbach alfa katsayıları sirasiyla .84, .80, $.79, .73, .78, .84$ ve .78 olarak; ölçeğin tamamı içinse .85 olarak belirtilmiştir (Doğanay ve ark., 2006).

\section{Verilerin Analizi}

Elde edilen verilerin analizinde öncelikli olarak normallik testleri ve betimsel istatistikler yapılmıştır. Verilerin normal dağılım göstermediği belirlenmiştir (Bkz Tablo 1). $\mathrm{Bu}$ nedenle gruplar aras1 karşılaştırma yapmak amacı ile Mann Whitney-U testi uygulanmıştır.

\section{BULGULAR}

Tablo 1. Çalişmaya Katilan Öğrencilerin Ölçek ve Alt Ölçeklerden Aldiklari Puanlara Ilişkin Betimsel Istatistikler

\begin{tabular}{|c|c|c|c|c|c|c|}
\hline Ölçek ve Alt Ölçekler & $\mathrm{n}$ & Min & Max & $\mathrm{X}_{\mathrm{orr}} \pm \mathrm{SS}$ & Skewnes & Kurtosis \\
\hline Akademik Öz-Yeterlilik Ölçeği & 4678 & 7.00 & 28.00 & $18.37 \pm 3.27$ & -1.040 & -2.107 \\
\hline Üniversite Yaşam Kalitesi Ölçeği & 4678 & 44.00 & 140.00 & $102.88 \pm 11.38$ & -1.494 & 2.385 \\
\hline Öğ. Elemanı-Öğrenci İlişkisi & 4678 & 6.00 & 29.00 & $18.73 \pm 3.43$ & -2.189 & 1.093 \\
\hline Kimlik & 4678 & 5.00 & 25.00 & $15.58 \pm 3.08$ & -2.133 & 1.004 \\
\hline Sosyal Alanlar & 4678 & 6.00 & 24.00 & $15.73 \pm 3.00$ & -2.137 & -2.240 \\
\hline Kararlara Katılım & 4678 & 6.00 & 25.00 & $15.61 \pm 2.94$ & -2.156 & -2.113 \\
\hline Gelecek & 4678 & 3.00 & 15.00 & $9.08 \pm 2.29$ & -1.941 & -2.287 \\
\hline Sinif Ortami & 4678 & 4.00 & 20.00 & $12.63 \pm 2.64$ & -.1856 & -2.233 \\
\hline Öğrenci-Öğgenci İlişkisi & 4678 & 4.00 & 20.00 & $12.51 \pm 2.55$ & -2.096 & -2.207 \\
\hline
\end{tabular}

Tablo 1'de verildiği gibi çalışmaya katılan öğrencilerin ölçek ve alt ölçeklerden aldıkları puanlar ölçek ortalama puanlarının üstündedir. Ayrıca ölçek ve alt ölçek puanlarına ilişkin Skewness ve Kurtosis değerlerinin 0.05 'ten küçük olması nedeniyle, verilerin normal dağılım göstermediği ortaya konmuştur (Tabachnick ve ark.,2001). Bu yüzden verilerin analizinde non-parametrik analizlerden yararlanılmıştır.

Tablo 2. Katılımcıların Akademik Öz-Yeterlik Puanlarının Cinsiyet Göre Karşılaştırılmasına İlişkin Mann-Whitney U Test Sonuçları

\begin{tabular}{lllll}
\hline Değişkenler & Cinsiyet & $\mathrm{N}$ & $\mathrm{X}_{\text {ort }} \pm \mathrm{SS}$ & $\mathrm{p}$ \\
\hline \multirow{2}{*}{ Akademik Öz-Yeterlik } & Erkek & 2493 & $18.50 \pm 3.27$ & \multirow{2}{*}{0.004} \\
\cline { 2 - 5 } & Kadın & 2185 & $18.21 \pm 3.26$ & \\
\hline
\end{tabular}

Tablo 2'de de görüldügü gibi katılımcıların akademik öz-yeterlik puan ortalamalarının cinsiyete göre farklılaştığ $\quad(p<.01)$ ve erkeklerin akademik öz-yeterlik puanlarının kadın öğrencilerden yüksek olduğu bulunmuştur. 
Çoşkun Özyol, F., Hamad Amin, M.B./Üniversite Öğrencilerinin Akademik Öz-Yeterlilik ve Yaşam Kalitelerinin Fiziksel Aktivite Yapma Durumlarına Göre İncelenmesi

Tablo 3. Katılımcıların Üniversite Yaşam Kalitesi Ve Alt Boyut Puanlarının Cinsiyete Göre Karşılaştırılmasına İlişkin Mann-Whitney U Testi Sonuçları

\begin{tabular}{|c|c|c|c|c|}
\hline Değişkenler & Cinsiyet & $\mathrm{n}$ & $\mathrm{X}_{\text {ort }} \pm \mathrm{SS}$ & $\mathrm{p}$ \\
\hline \multirow{2}{*}{ Yaşam kalitesi Toplam Puanı } & Erkek & 2493 & $103.77 \pm 11.62$ & \multirow{2}{*}{0.001} \\
\hline & Kadın & 2185 & $101.88 \pm 11.00$ & \\
\hline \multirow{2}{*}{ Öğretim Elemanı-Öğrenci İletişimi } & Erkek & 2493 & $17.97 \pm 3.26$ & \multirow{2}{*}{0.001} \\
\hline & Kadın & 2185 & $17.56 \pm 3.43$ & \\
\hline \multirow{2}{*}{ Kimlik } & Erkek & 2493 & $14.42 \pm 2.55$ & \multirow{2}{*}{0.034} \\
\hline & Kadın & 2185 & $13.36 \pm 2.63$ & \\
\hline \multirow{2}{*}{ Sosyal olanaklar } & Erkek & 2493 & $13.90 \pm 2.37$ & \multirow{2}{*}{0.048} \\
\hline & Kadın & 2185 & $13.66 \pm 2.63$ & \\
\hline \multirow{2}{*}{ Kararlara Katılım } & Erkek & 2493 & $17.28 \pm 2.85$ & \multirow{2}{*}{0.000} \\
\hline & Kadın & 2185 & $16.83 \pm 3.69$ & \\
\hline \multirow{2}{*}{ Öğrenci-Öğrenci İletişimi } & Erkek & 2493 & $11.45 \pm 2.08$ & \multirow{2}{*}{0.008} \\
\hline & Kadın & 2185 & $11.40 \pm 2.45$ & \\
\hline \multirow{2}{*}{ Gelecek } & Erkek & 2493 & $7.68 \pm 1.82$ & \multirow{2}{*}{0.023} \\
\hline & Kadın & 2185 & $8.16 \pm 2.57$ & \\
\hline \multirow{2}{*}{ Sinıf Ortamı } & Erkek & 2493 & $11.14 \pm 2.08$ & \multirow{2}{*}{0.018} \\
\hline & Kadın & 2185 & $11.50 \pm 2.92$ & \\
\hline
\end{tabular}

Tablo 3'te de verildiği gibi kadın ve erkek üniversite öğrencilerinin üniversite yaşam kalitesi puan ortalamaları arasında istatistiksel olarak anlamlı farklılık tespit edilmiştir. Öğretim Elemanı - Öğrenci İletişimi, Kimlik, Sosyal Olanaklar, Kararlara Katılım, Öğrenci - Ögrenci, İletişimi alt boyutlarında erkek öğrencilerin puanlarının kadın öğrencilerden daha yüksek olduğu; Gelecek ve Sinıf Ortamı alt boyutlarında ise kadın öğrencilerin puanlarının erkek öğrencilerden daha yüksek olduğu görülmüştür $(\mathrm{p}<.05)$. Üniversite yaşam kalitesi toplam puanında ise erkeklerin yaşamlarını daha kaliteli algıladıkları bulgusuna ulaşılmıştır $(\mathrm{p}<.00$

Tablo 4. Katılımcıların Akademik Öz-Yeterlik, Yaşam Kalitesi Ve Alt Boyut Puanlarının Fiziksel Aktivite Yapma Durumlarına Göre Karşılaştırılmasına İlişkin Mann-Whitney U Testi Sonuçları

\begin{tabular}{|c|c|c|c|c|}
\hline Değişkenler & $\begin{array}{l}\text { Fiziksel } \\
\text { Yapma }\end{array}$ & aktivite $\mathrm{N}$ & $\mathrm{X}_{\mathrm{ort}} \pm \mathrm{SS}$ & $\mathrm{p}$ \\
\hline \multirow{2}{*}{ Akademik Öz-Yeterlik Ölçeği } & Evet & 1417 & $18.35 \pm 3.30$ & \multirow{2}{*}{0.904} \\
\hline & Hayır & 3261 & $18.36 \pm 3.25$ & \\
\hline \multirow{2}{*}{ Yaşam Kalitesi Toplam } & Evet & 1417 & $102.80 \pm 11.80$ & \multirow{2}{*}{0.726} \\
\hline & Hayır & 3261 & $102.92 \pm 11.19$ & \\
\hline \multirow{2}{*}{ Öğretim Elemanı-Öğrenci İletişimi } & Evet & 1417 & $18.74 \pm 3.59$ & \multirow{2}{*}{0.853} \\
\hline & Hayır & 3261 & $18.72 \pm 3.35$ & \\
\hline \multirow{2}{*}{ Kimlik } & Evet & 1417 & $15.54 \pm 3.06$ & \multirow{2}{*}{0.611} \\
\hline & Hayır & 3261 & $15.59 \pm 3.09$ & \\
\hline \multirow{2}{*}{ Sosyal olanaklar } & Evet & 1417 & $15.60 \pm 3.00$ & \multirow{2}{*}{0.059} \\
\hline & Hayır & 3261 & $15.78 \pm 2.99$ & \\
\hline \multirow{2}{*}{ Kararlara Katılım } & Evet & 1417 & $18.60 \pm 3.37$ & \multirow{2}{*}{0.781} \\
\hline & Hayır & 3261 & $18.63 \pm 3.35$ & \\
\hline \multirow{2}{*}{ Öğrenci-Öğrenci İletişimi } & Evet & 1417 & $12.55 \pm 2.56$ & \multirow{2}{*}{0.473} \\
\hline & Hayır & 3261 & $12.49 \pm 2.54$ & \\
\hline \multirow{2}{*}{ Gelecek } & Evet & 1417 & $9.07 \pm 2.30$ & \multirow{2}{*}{0.996} \\
\hline & Hayır & 3261 & $9.07 \pm 2.28$ & \\
\hline \multirow{2}{*}{ Sinıf Ortamı } & Evet & 1417 & $12.66 \pm 2.65$ & \multirow{2}{*}{0.516} \\
\hline & Hayır & 3261 & $12.61 \pm 2.62$ & \\
\hline
\end{tabular}


Tablo 4'de de verildiği üzere öğrencilerin akademik öz-yeterlik ve üniversite yaşam kalitesi puanlarının fiziksel aktivite yapma durumlarına göre farklılaşmadığı ortaya çıkmıştır (p>.05).

\section{TARTIŞMA ve SONUÇ}

$\mathrm{Bu}$ araștırmada, Van Yüzüncü Y1l Üniversitesi lisans öğrencilerinin akademik öz yeterlik ve üniversite yaşam kalitesine ilişkin algıları belirlenmiş ve bu algıların cinsiyete ve fiziksel aktivite yapma durumuna göre farklılaşıp farklılaşmadığı sorgulanmıştır. Öğrencilerin cinsiyete göre akademik özyeterlik puanları değerlendirildiğinde, istatistiksel açıdan anlamlı bir fark bulunmamış ve buna karşın erkek öğrencilerin kadın öğrencilere kıyasla daha yüksek akademik öz-yeterlik algılarına sahip oldukları bulunmuştur. Alanyazın incelendiğinde araştırma bulgularını destekleyen ve öz-yeterlik algısının erkekler lehine farklılık gösterdiğini ortaya koyan çalışmaların daha fazla olduğu görülmektedir (Altunsoy ve ark., 2010; Alpay, 2010; Durdukoca, 2010; Johnson, 2011). Özsüer ve diğ. (2011)'nin 10910 öğrenci üzerinde yapmış oldukları araştırmada, öğrencilerin akademik öz-yeterlik puanların cinsiyet değişkenine göre farklılaştığ 1 ve erkek öğrencilerin akademik öz-yeterlik düzeylerinin kadın öğrencilerin akademik özyeterlik algılarından daha yüksek olduğu ortaya koymuştur (Özsüer ve ark., 2011). Benzer olarak cinsiyet faktörünün öz-yeterlik ve akademik başarı üzerindeki etkisini incelemek için yapmış olduğu çalışmada Busch (1995), kadın öğrencilerin erkek öğrencilere oranla daha düşük öz-yeterlik algılarına sahip oldukları sonucuna ulaşmıştır. Durdukoca (2010) ise yapmış olduğu çalışmada öğretmen adaylarının cinsiyete göre akademik öz-yeterlik algılarını araştırmak için yapmış olduğu çalışmada erkek öğretmen adayları lehine anlamlı bir farklılık elde etmiştir. Beden eğitimi spor öğretmen adaylarının akademik öz-yeterliklerinin incelendiği bir çok çalışmada, erkek beden eğitimi öğretmen adaylarının akademik özyeterlik algılarının kadın beden eğitimi öğretmen adaylarından daha yüksek olduğu bulunmuştur fakat elde edilen bu farkın istatistiksel olarak anlamlılık ifade etmediği ortaya konmuştur (Küçük ve ark., 2013; Ünlü ve ark., 2011; Y1lmaz ve ark., 2010). Diğer taraftan bu çalışmada elde edilen sonuçların ilgili alanyazın ile tutarlı olduğu söylenebilir. Nitekim literatürde yer bulan bir grup çalışmada cinsiyete göre kadın ve erkek öğrenciler arasında akademik öz-yeterlik algıları karşılaştırıldığında herhangi bir farkın bulunamadığı ileri sürülmüştür (Bozkurt, 2013; Varol, 2007; Yavuzer ve ark, 2002).

Öğrencilerin üniversite yaşam kaliteleri incelendiğinde ise erkek öğrencilerin toplam yaşam kalitesine ilişkin algılarının kadınlardan daha yüksek olduğu bulunmuştur. Aynı zamanda ölçegin alt boyutlarına bakıldığında, Öğretim Elemanı - Öğrenci İletişimi, Kimlik, Sosyal Olanaklar, Kararlara Katılım, Öğrenci - Öğrenci, İletişimi alt boyutlarında erkek öğrencilerin puanlarının yüksek olduğu; Gelecek ve Sinıf Ortamı alt boyutlarında ise kadın öğrencilerin puanlarının daha yüksek olduğu tespit edilmiştir. Bu çalışmada elde edilen bulgulara paralel olarak Pekel (2016) gerçekleştirmiş olduğu calışmada erkek öğrencilerin kadın öğrencilere kıyasla daha yüksek oranda yaşam kalitesi puanına sahip olduklarını bildirmiştir (Pekel, 2016). Diger taraftan, üniversitesite öğrencilerinin üniversite yaşam kalitesini belirlemek amacıyla yaptıkları çalışmada Doğanay ve Sarı (2006), cinsiyet faktörüne göre istatistiksel açıdan anlamlı bir fark bulunmadığını bildirmiştir (Doğanay ve ark., 2006). Bu sonuca paralel olarak Salıc1 (2010) da Beden Eğitimi ve Spor Yüksekokulu öğrencileri ile yapmış olduğu çalışmada cinsiyet değişkeninin üniversite yaşam kalitesi üzerinde anlamlı bir fark yaratmadığ 1 sonucuna ulaşmışlardır (Salıcı, 2010). Buna karşın Ren (2009) ve Low (2000) ise bu çalışmada elde edilen bulgulardan farklı olarak kadın öğrencilerin üniversitedeki yaşamlarına ilişkin memnuniyet seviyelerinin erkek öğrencilere oranla dikkat çekecek düzeyde yüksek olduğu sonucuna ulaşmıştır (Ren, 2009; Low, 2000).

Fiziksel aktivite, yaşamın bir çok alanında her yaş grubunda doğru, yeterli ve düzenli olarak uygulandığında pozitif yönde etkili olan bir 
olgudur (Malina, 2001). Fiziksel aktivite etkinliklerine katılan bireyler sosyal yaşam içerisinde kendilerine bir statü kazandırmış olurlar. Son yıllarda bir çok alanda sosyalleşme aracı olarak kullanılan fiziksel aktivite, insanları bir arada tutarak daha kaliteli zaman geçirmelerine neden olduğu için önemi her geçen gün artmaktadır (Rhodes ve ark.,2009). Bu bağlamda fiziksel aktivite yapmanın sosyalleştirici ve birleştirici etkisi dikkate alındığında, fiziksel aktivite yapanların yapmayanlara oranla özgüven ve öz-yeterlik yönünden daha yüksek düzeyde olması normal karşılanabilir (Bonevski, 2014). Ancak yapılan bu çalışmada yer alan öğrencilerin akademik öz-yeterlik ve üniversite yaşam kalitesi puanları fiziksel aktivite yapma durumuna göre karşılaştırıldığında istatistiksel açıdan anlamlı bir farklılık görülmemiştir. Alanyazın incelendiğinde fiziksel aktivite yapma durumuna göre, üniversite yaşam kalitesinin ve akademik öz-yeterliliğin incelendiği çalışmaya rastlanmamıştır.

$\mathrm{Bu}$ çalışma sonucunda elde edilen bulgular ve daha önceki araştırma bulgularına bakıldığında erkek öğrencilerin toplam üniversite yaşam kalitesi puanları ve akademik öz-yeterlik algılarının kadın öğrencilerden daha yüksek olduğu sonucu gözlemlenmiştir. Buna karşın, üniversite öğrencilerinin akademik öz-yeterlik ve yaşam doyumu puanlarının fiziksel aktivite yapma durumuna göre farklılaşmadığ $\breve{g}_{1}$ bulunmuştur. Özetle, elde edilen sonuçların büyük ölçüde alanyazında bulunan çalışmalar ile örtüşmekte olduğunu söylemek mümkündür.

Yukarıda ifade edilen bulgular 1şığında üniversite öğrencilerinin yaşamlarının büyük bir kısmını üniversitede geçirdiklerini göz önünde bulundurulduğunda, üniversite öğrencilerinin akademik öz-yeterlikleri ve üniversite yaşam kalitelerini konu alan bu çalışmanın üniversite gençliğinin daha iyi tanınmasına destek olacağı düşünülmektedir. Ancak, yapılan bu araştırmanın bir takım sinırlılıkları da vardır. $\mathrm{Bu}$ doğrultuda araştırmanın farklı üniversitelerde ve farklı öğretim programlarına devam eden (önlisans, doktora vb.) üniversite öğrencileri ile tekrarlanmasının, bu araştırma sonuçlarının genellenebilirliğine katk1 sağlayacağı düşünülmektedir. Ayrıca benzer çalışmanın fiziksel aktivite yapma durumunun yanı sira planlı egzersiz programına katılım ve spor yapma durumuna göre incelenmesi de araştırmanın genellenebilirliğini arttırabilir.

\section{KAYNAKÇA}

Altun, F. \& Yazıc1, H. (2012). Yetenekli öğrencilerin benlik kavramları ve akademik öz-yeterlik inançları karşılaştırmalı bir çalışma. Mehmet Akif Ersoy Üniversitesi Eğitim Fakültesi Dergisi, 12 (23): 319-334.

Altun, F. \& Yazıc1, H. (2013). Ergenlerin benlik algılarının yordayıcıları olarak: akademik öz-yeterlik inanc1 ve akademik başarı. Kastamonu Eğitim Dergisi, 21 (1), 145156.

Altunsoy, S., Çimen, O., Ekici, G., Atik, A. D. \& Gökmen, A. (2010). An assessment of the factors that influence biology teacher candidates' levels of academic selfefficacy, (Vol 2, p. 2377-2382). Procedia Social and Behavioral Sciences.

Antaramian, S. (2017). The importance of very high life satisfaction for students' academic success. Cogent Education, 4 (1).

Argon, T. \& Kösterelioğlu, M. A. (2009). Üniversite öğrencilerinin üniversite yaşam kalitesi ve fakülte kültürüne ilişkin algiları. Elektronik Sosyal Bilimler Dergisi, 8 (30): 43-61.

Aypay, A. (2010). Genel Öz Yeterlik Ölçeği'nin (GÖYÖ) Türkçe'ye uyarlama çalışması. İnönü Üniversitesi Eğitim Fakültesi Dergisi,11 (2): 113-131.

Bandura, A. (1997). Self-efficacy: The exercise of control. New York: Freeman.

Bandura, A. (2000). Exercise of human agency through collective efficacy. Current Directions in Psychological Science, 9 (3) 75-78.

Bonevski, B. (2014). The vocational education setting for health promotion: a survey of students' health risk behaviours and preferences for help. Health Promotion Journal of Australia, 24 (3): 185-191.

Bozkurt, M. T. (2013). Beden eğitimi ögrretmeni adaylarının ögretmenlik öz yeterliklerinin incelenmesi, Yayınlanmamış Yüksek Lisans Tezi. Ankara: Gazi Üniversitesi, Eğitim Bilimleri Enstitüsü, Beden Eğitimi ve Spor Öğretmenliği Ana Bilim Dalı. 
Busch, T. (1995). Gender differences in selfefficacy and academic performance among students of business administration. Scandinavian Journal of Educational Research, 39 (4), 311-318.

Caprara, G. V., \& Steca, P. (2005). Self-efficacy beliefs as determinants of prosocial behavior conducive to life satisfaction across ages. Journal of Social and Clinical Psychology, 24 (2), 191-217.

Doğanay, A. \& Sarı, M. (2006). Öğrencilerin üniversitedeki yaşam kalitesine ilişkin algılarının demokratik yaşam kültürü çerçevesinde değerlendirilmesi. Çukurova Üniversitesi örneği. Türk Ĕ̈itim Bilimleri Dergisi, 4 (2), 107-128.

Durdukoca, Ş. F. (2010). Sinıf ögretmeni adaylarının akademik özyeterlik algılarının çesitli degişkenler açısından incelenmesi. Abant Izzet Baysal Üniversitesi Dergisi, 10 (1), 69-77.

Ekici, G. (2009). Biyoloji öz-yeterlik ölçeğinin Türkçeye uyarlanması. Kastamonu Eğitim Dergisi, 17 (1), 111-124.

Erdem, N. (2005). Diyaliz hastalarında progresif gevşeme egzersizlerinin uyku ve yaşam kalitesine etkisinin incelenmesi. Yayımlanmış Doktora Tezi. Erzurum: Atatürk Üniversitesi Sağlık Bilimleri Enstitüsü.

Güldü, S. (2015). Liselerde okuyan öğrencilerin görüşleri doğrultusunda okul metaforlar,, akademik öz yeterlik ve lise yaşam kalitesi arasındaki ilişkinin incelenmesi. Yayımlanmamış Yüksek Lisans Tezi. Gaziantep Zirve Üniversitesi Eğitim Bilimler Enstitüsü.

Güney, Z. (2004). Sağllk yöneticilerinin yaşam kalitesinin belirlenmesi (Ankara ili örneği). Yayımlanmamış Yüksek Lisans Tezi. Ankara: Atılım Üniversitesi Sosyal Bilimler Enstitüsü İşletme Anabilim Dalı Sağlık Kurumlar İşletmeciliği Bilim Dalı.

Hermann, K. S. (2005). The influence of social self-efficacy, self-esteem and personality differences on loneliness and depression. Unpublished Doctoral Dissertation. Ohio State University.

Huebner, E. S., Suldo, S. M., Smith, L. C., \& McKnight, C. G. (2004). Life satisfaction in children and youth: Empirical foundations and implications for school psychologists [Special issue]. Psychology in the Schools, 41 :81-93.

Jerusalem, M. \& Schwarzer, R. (1981). Fragebogen zur Erfassung von Selbstwirksamkeit. Skalen zur Befindlichkeit und Persoenlichkeit In R.
Schwarzer (Hrsg.). (Forschungsbericht No.5). Berlin: Freie Universitaet, Institut fuer Psychologie.

Jerusalem, M. (2002). Theroretischer Teil Einleitung I. Zeitschrift für Pädagogik, 44 : 8-12.

Johnson, K. F. (2011). The influence of school connectedness and academic self efficacy on self-reported norm related pro-social beh avior. Unpublished Doctoral Dissertation. Pennsylvania: Pennsylvania State University.

Kabeta, M. H. (1999). University productive sector linkages for quality of life 1mprovement. Institute Of Distance Education: 112.

Kandemir, M. (2014). Akademik ertelemenin yordayıcıları: Sorumluluk, başarı/başarısızlığa yönelik Yükleme Stilleri ve Akademik Özyeterlik İnançları. Education and Science, 39 (171), 99-114.

Kinzie, M. B., Delcourt, M. A. B., \& Powers, S. M. (1994). Computer technologies: Attitudes and self-efficacy across undergraduate disciplines. Research and Higher Education, 35: 745-768.

Küçük, K., S. \& Öncü, E. (2013). 6.Ulusal Spor Bilimleri Öğrenci Kongresi: Beden eğitimi ve spor yüksekokulu öğrencilerinin bilişötesi öğrenme stratejileri ve akademik öz-yeterlikleri. Kayseri: Erciyes Üniversitesi.

Low, L. (2000). Are college students satisfied? A national analysis of changing expectations. New Agenda Series [TM]. Indianapolis: USA Group Inc, 29-33.

Malina, RM (2001). Physical activity and fitness: pathways from childhood to adulthood. American Journal of Human Biology, 13(2), 162-172

Özbay, Y., Palancı, M., Kandemir, M. \& Çakııı, O., (2012). Üniversite öğrencilerinin öznel iyi oluşlarının duygusal düzenleme, mizah, sosyal özyeterlik ve başaçıkma davranışları ile yordanması. Türk Eğitim Bilimleri Dergisi, 10 (2), 325-345.

Özsüer, S., İnal, G., Uyanık, Ö., Ergün, M. (2011). Afyon Kocatepe Üniversitesinde öğrenim gören öğrencilerin akademik özyeterlik inanç düzeylerinin incelenmesi. Sosyal Bilimler Dergisi, 13 (2), 113-125.

Pekel, A. (2016). Spor yöneticiliği bölümünde ögrenim gören ögrencilerinin akademik öz yeterlikleri ve üniversite yaşam kalitesi arasındaki ilişkinin incelenmesi. Yayınlanmamış Yüksek Lisans Tezi. Kayseri: Erciyes Üniversitesi Sağlık 
Bilimleri Enstitüsü, Beden Eğitimi ve Spor Anabilim Dali.

Ren, W. (2009). A research on the subject wellbeing of regional college students. International Journal of Psychological Studies, 1 (1), 51-53.

Rhodes R.E., Dean R.N. (2009). Understanding physical inactivity: Prediction of four sedentary leisure behaviors. Leisure Sciences, 31(2): 124-135.

Salıc1, O. (2010). Beden eğitimi ve spor yüksekokulu öğrencilerinin üniversitedeki yaşam kalitesine ilişkin algılarının demokratik yaşam kültürü çerçevesinde değgerlendirilmesi, Yayımlanmış Yüksek Lisans Tezi. Adana: Çukurova Ünşversitesi Sağlık Bilimleri Enstitüsü, Beden Eğitimi ve Spor Anabilim Dali.

Sarı, M. (2007). Demokratik Değerlerin Kazanımı Sürecinde Örtük Program: Düşük ve Yüksek "Okul Yaşam Kalitesine Sahip Iki Illkögretim Okulunda Nitel Bir Çalışma. Yayımlanmış Doktora Tezi. Adana: Çukurova Üniversites Eğitim Bilimleri Enstitüsü.

Schunk, D. H. (1991). Self-efficacy and Academic Motivation. Educational Psychologist, 26, 207-231.

Seki, T., Şimşir, Z., Dilmaç, B., Bircan, H. H., \& Baykan, E. (2018). Üniversite öğrencilerinin fakülte yaşamının nitelikleri, akademik öz yeterlik ve öznel iyi oluşları arasındaki yordayıcı ilişkiler. Eğitim Bilimleri Dergisi, 48: 164-178.

Tabachnick, B. G., \& Fidell, L. S. (2001). Using multivariate statistics. Allyn and Bacon. Needham Heights, MA.

Tamannaeifar, M. R., \& Motaghedifard, M. (2014). Subjective well-being and its subscales among students: The study of role of creativity and self-efficacy. Thinking Skills and Creativity, 12: 37-42.

Telef, B. B., Ergün, E. (2013). Lise öğrencilerinin öznel iyi oluşlarının yordayıcısı olarak öz-yeterlik. Kuramsal Eğitimbilim Dergisi, 6 (3), 423-433.

Ünlü, H, Kalemoğlu, Y. (2011). Academic selfefficacy of Turkish physical education and sport school students. Journal of Human Kinetics, 27: 190-203.

Varol, B. (2007). Beden eğitimi ve spor bölümü ögrencilerinin öğretmenlik mesleğine ilişkin öz yeterlikleri, Niğde örneği. Yayımlanmış Yüksek Lisans Tezi. Nigde: Niğde Üniversitesi Sosyal Bilimler Enstitüsü Eğitim Bilimleri Anabilim Dalı.
Vecchio, G. M., Gerbino, M., Pastorelli, C., Del Bove, G., \& Caprara, G. V. (2007). Multifaceted self-efficacy beliefs as predictors of life satisfaction in late adolescence. Personality and Individual Differences, 43 (7), 1807-1818.

Wilcox, G. \& Nordstokke, D. (2019). Predictors of university student satisfaction with life, academic self efficay and achievement in the first year. Canadian Journal of Higher Education, 49 (1), 104- 124.

Yavuzer, Y. ve Koç, M. (2002). Eğitim fakültesi öğrencilerinin öğretmen yetkinlikleri üzerinde bir değerlendirme. Niğde Üniversitesi Eğitim Fakültesi Dergisi, 1 (1), 20-25.

Y1lmaz, İ., Yoncalık, O., Ulucan, H. (2010). 11th International Sports Sciences Congress: Examining the belief of academic selfefficacy and teacher selfefficacy of physical education teacher candidates in terms of various variables. Antalya: Gazi University.

Yılmaz, M., Gürçay, D., Ekici, G. (2007): Akademik öz yeterlik ölçeğinin Türkçeye uyarlanmas1. Hacettepe Üniversitesi Eğitim Fakültesi Dergisi, 33, 253-259. 